\title{
COGNITIVE DIVERSITY AMONG EFL LEARNERS: IMPLICATIONS FOR TEACHING IN HIGHER EDUCATION
}

\author{
Tariq Elyasa ${ }^{a}$, Bayan AlHashmi ${ }^{\mathrm{b}}$, Fan Fang ${ }^{\mathrm{c}}$

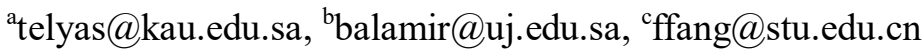 \\ ${ }^{a}$ King Abdulaziz University \\ 25 Al Jamaa Street, Jeddah, Saudi Arabia \\ ${ }^{b}$ University of Jeddah \\ Hamzah Ibn Al Qasim Street, Al Sharafeyah, Jeddah, Saudi Arabia, 23218 \\ 'Shantou University \& King Abdulaziz University \\ 243 Daxue Road, Shantou, Guangdong, China, 515063
}

\begin{abstract}
With a theory-driven interest in the factors that make some language learners more successful than others, this study attempts to measure the cognitive diversity level of EFL learners at a Saudi university. To achieve this purpose, the Ehrman and Leaver's questionnaire of learners' cognitive profiles (Ehrman \& Leaver, 2003) was adapted, translated into Arabic, and then randomly distributed to foundation year students taking English as a Foreign Language as a main course. The overall results reveal that the cognitive diversity among students is considerable. It ranges between moderate to high, according to the Simpson Diversity Index (Simpson, 1949). On this account, several implications are suggested to improve the quality of EFL teaching at the university level. These implications and recommendations are mostly directed to the committees concerned with qualification assurance or professional development.
\end{abstract}

Keywords: differentiated instruction, E \& L construct, English as a Foreign Language (EFL), grammar learning, Simpson Diversity Index

DOI: http://dx.doi.org/10.15639/teflinjournal.v31i1/44-69 
Ever since the beginning of their collaboration, the fields of psychology and education have been studying two opposing elements: the general characteristics of learners' minds and the distinctiveness of individual learners (Dörnyei, 2014). The latter has become a key factor in the question of why some second language learners are successful, whereas others are not and why this success differs from one learner to another (Lightbown \& Spada, 2013; Stephens, 2017). According to Brown (2006), second language development is marked by 'systematicity' and 'variability'. It is systematic in the sense that it develops in a way similar to that of a first language and variable because it can be easily affected by cognitive and affective factors. Consequently, to deliver an effective instruction in second language settings, teachers are advised to provide students with appropriate access to language lessons. One way of doing so is through the implementation of what is called 'differentiated instruction' (Tomlinson, 2014).

It is important that research of individual differences can be further explored in language classroom instruction to understand learners' needs and goals. In some situations, learners' cognitive and affective factors cannot be directly observed, but these factors play an important role in language acquisition process. Therefore, this area of study has inspired researchers to explore the nature of individual differences among language learners and their impact on their own learning (Dörnyei, 2014; Mazloomi \& Khabiri, 2018; McNamara \& Deane, 2006; Vakil \& Ebadi, 2019). In Saudi Arabia, for example, although teachers have realized the importance of individual differences in language learning, empirical research is still scarce. Guided by Ehrman and Leaver's (E \& L) model of cognitive styles (Leaver et al., 2005), the current study therefore aims at measuring the degree to which English as a Foreign Language (EFL) students in Saudi Arabia differ in terms of their cognitive profiles and the way they process new information presented in class.

\section{Literature Review}

Language learners' individual differences can be traced back to three educational theories: The Complex Theory (Ortega \& Han, 2017), Constructivism (Jones \& Brader-Araje, 2002), and the Zone of Proximal Development (ZPD) (Bozhovich, 2009). Research of individual differences eclectically follows some of the main principles of each theory. It follows the Complex Theory in its definition of language learning as a complex system, 
Constructivism in its description of the source of knowledge and the way it is constructed, and the ZPD in its emphasis on knowing what the learner is capable of and planning for what she/he will be able to do in the future.

\section{Learning Theories}

Breaking the conventions of Realism and Objectivism which claim that knowledge is external and independent of the learners or observers, Constructivism assumes that knowledge is the result of "mental construction" (Olusegun, 2015). This process of mental construction involves individual properties of the learners (Larochelle et al., 1998). Hence, central to this theory is the premise that the individual student plays the most critical role in meaning-making processes.

Constructivist instructional activities (Jones \& Brader-Araje, 2002) start by discovering students' abilities, skills and prior experiences, then provide them with opportunities through which they can develop intellectually. Constructivism, as a result, views learning as an active process, rather than a rigid one. This is particularly important when viewing the diversity of language as well as its learning process. Language is not learned in a vacuum; instead, it is learned through various means of exposure both consciously and unconsciously (Fang, 2017, 2018; Seidlhofer, 2011).

The Zone of Proximal Development (ZPD) is one of the main aspects of Vygotsky's (1978) Sociocultural Theory, which was first promoted in the $18^{\text {th }}$ and $19^{\text {th }}$ century (Lantolf et al., 2015). It refers to "the distance between the actual developmental level as determined by independent problem solving and the level of potential development as determined through problem-solving under adult guidance or in collaboration with more capable peers" (Vygotsky, 1978, p. 86).

The basic idea behind ZPD is to provide learners with meaningful instruction and problem-solving activities within their own Zones of Proximal Development (Roosevelt, 2008). To do so, teachers are expected to bring into the classroom materials that are slightly above students' current level and support them until they reach a level where they can work independently. Lantolf et al. (2015) added that the ZPD is not about the amount of support or assistance given by the expert to the novice learner but the quality of mediation. For that reason, the teachers' role extends to include planning for purposeful instruction and designing activities and experiences that allow learners to reach their potentials (Subban, 2006). 


\section{Learning Preferences or Styles}

The term 'individual differences' is defined as "dimensions of enduring personal characteristics that are assumed to apply to everybody and on which people differ by degree" (Dörnyei, 2014, p. 4). These dimensions are numerous and various. Consequently, the argument about what are the most important ones is broad; and many proposals have been made regarding what causes individuals to be different.

Before clarifying what is meant precisely by learning preference or styles, it is important to mention that in the literature of language learning, there is some confusion over the meaning of this term and learning strategies (Brown, 2006). This confusion might lead researchers to question the effectiveness of styles-based instruction, as will be explained later. To clear up the confusion, Brown (2006) defines learning styles as consistent tendencies or preferences within a person. These tendencies are fixed and unconscious in the sense that they are difficult to change, and they operate without the learners being aware of them (Dörnyei, 2014). Learning strategies, on the other hand, are defined as the "specific actions one takes and techniques one uses to learn" (Leaver et al., 2005, p. 65). These actions can be learned and involve freedom of choice (Dörnyei, 2014). In other words, learning styles are abstract and stable tendencies, whereas learning strategies are observable and changeable actions.

\section{$\boldsymbol{E} \&$ L Construct}

The E \& L Construct, developed by Ehrman and Leaver (Leaver et al., 2005 ) is one of the most prevalent models of cognitive styles. It comprises ten continuum-like scales: 1) Analogue-digital, 2) Concrete-abstract, 3) Field independent-field dependent, 4) Field sensitive-field insensitive, 5) Globalparticular, 6) Impulsive-reflective, 7) Inductive-deductive, 8) Levelingsharpening, 9) Random-sequential, 10) Synthetic-analytic.

\section{Analogue-Digital Scale}

This scale addresses the degree to which learners like to work at more superficial or deep levels. Analogue learners prefer the use of figurative language; the language used in analogies, metaphors, conceptual relations. Digital learners, on the other hand, prefer to approach the material on a more surface level. They are straightforward learners whose understanding of what they hear is hugely literal (Dörnyei, 2014). 


\section{Concrete-Abstract Scale}

In general, the concrete-abstract scale considers the degree to which learners prefer the use of hands-on activities. Concrete learners prefer to have a direct relationship with materials to the extent of sensory contact, while abstract learners tend to be more interested in the system that underlies a language than in the language used for communication (Dörnyei, 2014). Ehrman and Leaver (2003) further illustrated the idea behind this scale and pointed out that in language classrooms, concrete learners prefer to do something real with the language, not just learning about it. Abstract learners, on the other hand, prefer to discuss abstract notions and topics, paying more attention to accuracy at the expense of fluency.

\section{Field Independent-Field Dependent and Field Sensitive-Field Insensitive Scales}

Due to their interchangeability in much of the current body of literature on cognitive styles, these two scales are to be discussed, here, in relation to each other. According to Dörnyei (2014), field-dependence is decided by the degree of someone's tendency to select and prioritize, whereas field-sensitivity is more related to making use of the learning fore- and back-ground. Field-independent learners are the ones who are capable of picking up and distinguishing specific elements of the learning materials, whereas field-dependent learners are the ones who treat the whole context as the same. Field-sensitive learners, on the other hand, are those who use the whole learning environment as a source of information including conversations between the teacher and other students, wall posters. Ehrman (1996) reported the presence of four types of learners described as shown in Table 1.

Table 1. Characteristics of Field Dep. and Field Sens. Learners

\begin{tabular}{cccc}
\hline & Field Dep. & Fiend Sens. & Characteristics \\
\hline Type 1 & + & + & Learn best from in-context materials \\
Type 2 & - & + & Can handle in- and out- of context materials \\
Type 3 & - & - & Learn best from out-of-context materials \\
Type 4 & + & - & Face challenges with both types of materials \\
\hline
\end{tabular}




\section{Global-Particular Scale}

This scale, according to Leaver et al. (2005), refers to learners" "breadth of focus". Global learners are the ones who prefer to see and understand the whole picture using "top-down" processes, and vice versa; particular learners are the ones who pay careful attention to discrete and minimal units using "bottom-up" learning strategies. It is worth mentioning at this point, however, that this scale describes the direction in which information-processing is moving, whereas when it comes to the Analytic-Synthetic scale, it is the final result that matters.

\section{Impulsive-Reflective Scale}

This scale refers to the "speed of processing a response to a stimulus" (Ehrman \& Leaver, 2003, p. 402). Impulsive learners, thus, are the ones who respond back to something rapidly, often acting on guts, while reflective learners are the ones who take their time to think before they respond (Dörnyei, 2014). Furthermore, impulsive learners are frequently active; they like to comment on most of the topics and are highly initiative when it comes to new tasks or projects. Reflective learners, on the other hand, experience more complex thinking skills and produce work with more accuracy.

\section{Inductive-Deductive Scale}

Inductive learners start out by viewing examples and details, create hypotheses, and then test them. Deductive learners, on the contrary, start out by learning the rules and then apply them to specific cases. According to Ehrman and Leaver (2003), inductive learners may find explanations given by their teachers very intrusive. Thus, they usually have better control of a grammar rule a few days after it has been introduced. Deductive learners, on the other hand, prefer to get the grammar rule from the teacher rather than finding it out themselves.

\section{Leveling-Sharpening Scale}

This dimension describes how learners perceive information, store it in their minds and retrieve it later on. Levelers often meld things together and form a general image. To do so, they often see the similarities between things and neglect differences. Sharpeners, on the contrary, tend to pay attention to 
small differences and store them in their minds as salient elements (Dörnyei, 2014). According to Ehrman and Leaver (2003), levelers find contrastive analysis and analogies frequently tricky because they only focus on similarities.

\section{Random-Sequential Scale}

This scale describes the degree to which a learner needs some external intervention in order to organize the materials. Unlike others, random learners have more tendency to tolerate surprises and accept ambiguity very well (Ehrman \& Leaver, 2003). They are successful at creating and following their own individual order of materials (which might appear random to other learners). Sequential learners, on the other hand, prefer the norm; a step-bystep guidance and an external order of materials. These learners get relatively frustrated and uncomfortable when faced with very open-ended or hands-on classroom activities (Dörnyei, 2014).

\section{Synthetic-Analytic Scale}

Synthetic students prefer to build new wholes out of smaller pieces. They have the following characteristics: 1) they intuitionally form hypotheses, 2) they move from insights to constructs; 3 ) they have the ability to read, combine their reading with other ideas and form whole new ideas. Analytic learners, on the other hand, prefer to analyze and dissemble wholes into pieces. Moreover, analytic learners have the following characteristics: 1) they consciously build up new hypotheses, 2) they move from constructs to insights, 3) they like activities that require them to split words and sentences into pieces.

Readers of the E \& L Construct can intuitively notice that all of the nine scales fall under another umbrella scale. The larger scale is made up of two poles: Synoptic and Ectenic (Leaver et al., 2005). Synoptic learning relies on students' unconscious control over their learning, whereas Ectenic learning occurs under (Skehan, 1998). This section has introduced 'individual differences' as a significant element of second language learning. Under this section, the discussion has been broadened to include cognitive styles and the $\mathrm{E}$ \& L Construct. Individual differences, in general, and cognitive styles, in particular, play a vital role in deciding the best method to use when teaching a language. 


\section{METHOD}

To measure the degree of cognitive diversity among learners, Ehrman and Leaver's (2003) cognitive styles questionnaire was adapted. The questionnaire was piloted during the third module in the first semester of an academic year (see Appendix 1). Using Statistical Package for Social Sciences (SPSS), the Cronbach's Alpha (a measurement of internal consistency) was found to be 0.723, which is, according to Dörnyei and Csizer (2012), within the normal range (0-1) and exceeds (0.7), the value above which the reliability level is regarded as "acceptable" (see Table 2).

Table 2. Cronbach's Alpha of the Questionnaire Items (Cronbach, 1951)

\begin{tabular}{cc}
\hline \multicolumn{2}{c}{ Reliability Statistics } \\
\hline Cronbach's Alpha & N of Items \\
\hline .723 & 26 \\
\hline
\end{tabular}

The questionnaire was then distributed randomly to 123 preparatory year students at the beginning of the third module in their tertiary educational level. The reason behind this random distribution was to ensure that the results are as representative as possible of the whole population, the preparatory year students at a given university. With random sampling, each individual has an equal probability of being selected from the population, ensuring that the sample will be representative of the population in a given context (Kepple, 1991) assuring this is a true experiment.

To analyze the E \& L questionnaire results, the SPSS Statistics as well as Microsoft Excel were employed respectively. The former was first used to find the frequencies and percentages of responses, and the latter to calculate the Simpson's Diversity Index (DI) (1949) for each scale as shown in Table 3.

Table 3. Simpson's Diversity Index Scale (Simpson, 1949)

\begin{tabular}{ccccc}
\hline Extremely high & High & Moderate & Low & Extremely low \\
\hline $0.1-0.2$ & $0.3-0.4$ & $0.5-0.6$ & $0.7-0.8$ & $0.9-1$ \\
\hline
\end{tabular}


According to Jarvis (2013), "Simpson's Index reflects the probability of randomly choosing two individuals of the same category twice in succession" (p. 93). The central point of Simpson's index is to construct a vector of probabilities, i.e. all elements of the vector are greater than or equal to zero and they sum to one. The relationship between these two parameters suggests that diversity patterns of the metacommunity can also be equally described by the Simpson's Diversity index. In turn, this "relationship provides an alternative approach to interpret and estimate the fundamental biodiversity parameter for the metacommunity" (He \& Hu, 2005, p. 386). However, "Simpson's Index outputs a precise probability rather than a value located on a scale that is difficult to interpret" (Jarvis, 2013, p. 93). From the name itself, DI is a measure of diversity across a community which considers the richness and evenness of the society's members. The value of DI, as illustrated in Figure 1, ranges from 0 (all categories are equally present) to 1 (one category dominates the whole community) (Hammer et al., 2001).

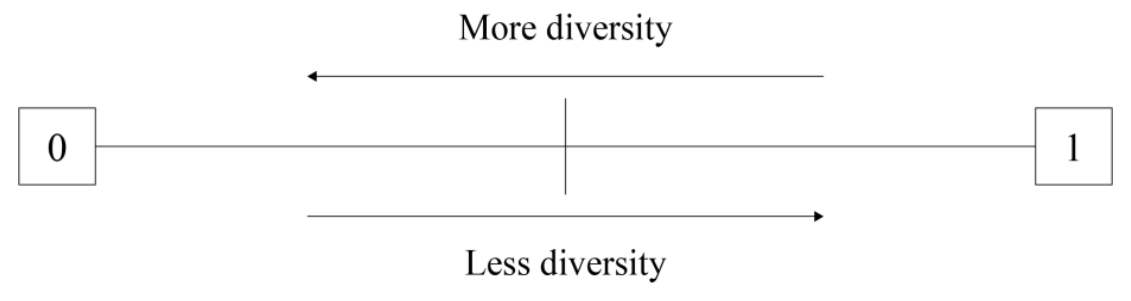

Figure 1. Value of DI in Simpson's Diversity Index Scale (Hammer et al., 2001)

According to Kwak \& Peterson (2007), DI is calculated by:

$$
1-\sum_{i=1}^{k} \frac{n_{i}\left(n_{i}-1\right)}{n(n-1)}
$$

The " $n$ " in this formula represents the total number of the whole community, while " $n_{i}$ " represents the total number of individuals in a particular category. 


\section{FINDINGS AND DISCUSSION}

To answer the research question of whether EFL students at a tertiary educational level differ in terms of their cognitive styles, the adapted English version of Ehrman and Leaver's questionnaire was used (See Appendix 1). The questionnaire results, as shown in Table 4 were analyzed descriptively.

Table 4. Students' Responses to the E \& L Cognitive Styles Questionnaire

\begin{tabular}{|c|c|c|c|c|c|c|}
\hline Scale & Item & & Frequency & $\%$ & $\begin{array}{c}\text { Simpson } \\
\text { In. }\end{array}$ & Average \\
\hline \multirow{9}{*}{$\begin{array}{l}\text { Field (in)- } \\
\text { sensitivity }\end{array}$} & \multirow{3}{*}{1} & Field Sens. & 26 & 31.3 & \multirow{3}{*}{0.449309} & \multirow{9}{*}{0.512685} \\
\hline & & Situational & 8 & 9.6 & & \\
\hline & & $\begin{array}{l}\text { Field In- } \\
\text { Sens. }\end{array}$ & 49 & 59.0 & & \\
\hline & \multirow{3}{*}{11} & Field Sens. & 20 & 24.1 & \multirow{3}{*}{0.54452} & \\
\hline & & Situational & 5 & 6.0 & & \\
\hline & & $\begin{array}{c}\text { Field } \\
\text { In.Ses. }\end{array}$ & 58 & 69.9 & & \\
\hline & \multirow{3}{*}{19} & Field Sens. & 15 & 18.1 & \multirow{3}{*}{0.544226} & \\
\hline & & Situational & 9 & 10.8 & & \\
\hline & & $\begin{array}{l}\text { Field In- } \\
\text { Sens. }\end{array}$ & 59 & 71.1 & & \\
\hline \multirow{6}{*}{$\begin{array}{l}\text { Field (in)- } \\
\text { dependence }\end{array}$} & \multirow{3}{*}{2} & $\begin{array}{l}\text { Field } \\
\text { Indep. }\end{array}$ & 20 & 24.1 & \multirow{3}{*}{0.500441} & \multirow{6}{*}{0.486336} \\
\hline & & Situational & 8 & 9.6 & & \\
\hline & & Field Dep. & 55 & 66.3 & & \\
\hline & \multirow{3}{*}{20} & $\begin{array}{c}\text { Field } \\
\text { Indep. }\end{array}$ & 23 & 27.7 & \multirow{3}{*}{0.47223} & \\
\hline & & Situational & 8 & 9.6 & & \\
\hline & & Field Dep. & 52 & 62.7 & & \\
\hline \multirow{6}{*}{$\begin{array}{l}\text { Leveling- } \\
\text { sharpening }\end{array}$} & \multirow{3}{*}{3} & Leveling & 55 & 66.3 & \multirow{3}{*}{0.497208} & \multirow{6}{*}{0.418601} \\
\hline & & Situational & 9 & 10.8 & & \\
\hline & & Sharpening & 19 & 22.9 & & \\
\hline & \multirow{3}{*}{12} & Leveling & 29 & 34.9 & \multirow{3}{*}{0.339994} & \\
\hline & & Situational & 20 & 24.1 & & \\
\hline & & Sharpening & 34 & 41.0 & & \\
\hline \multirow{2}{*}{$\begin{array}{c}\text { Global- } \\
\text { particular }\end{array}$} & \multirow{2}{*}{4} & Global & 27 & 32.5 & \multirow{2}{*}{0.431384} & \multirow{2}{*}{0.567147} \\
\hline & & Situational & 9 & 10.8 & & \\
\hline
\end{tabular}


54 TEFLIN Journal, Volume 31, Number 1, January 2020

\begin{tabular}{|c|c|c|c|c|c|c|}
\hline Scale & Item & & Frequency & $\%$ & $\begin{array}{l}\text { Simpson } \\
\text { In. }\end{array}$ & Average \\
\hline & & Particular & 47 & 56.6 & & \\
\hline & \multirow{3}{*}{21} & Global & 9 & 10.8 & \multirow{3}{*}{0.702909} & \\
\hline & & Situational & 5 & 6.0 & & \\
\hline & & Particular & 69 & 83.1 & & \\
\hline \multirow{9}{*}{$\begin{array}{l}\text { Impulsive-- } \\
\text { reflective }\end{array}$} & \multirow{3}{*}{5} & Impulsive & 29 & 34.9 & \multirow{3}{*}{0.391713} & \multirow{9}{*}{0.428739} \\
\hline & & Situational & 12 & 14.5 & & \\
\hline & & Reflective & 42 & 50.6 & & \\
\hline & \multirow{3}{*}{13} & Impulsive & 47 & 56.6 & \multirow{3}{*}{0.436967} & \\
\hline & & Situational & 8 & 9.6 & & \\
\hline & & Reflective & 28 & 33.7 & & \\
\hline & \multirow{3}{*}{22} & Impulsive & 52 & 62.7 & \multirow{3}{*}{0.457537} & \\
\hline & & Situational & 13 & 15.7 & & \\
\hline & & Reflective & 18 & 21.7 & & \\
\hline \multirow{9}{*}{$\begin{array}{l}\text { Synthetic- } \\
\text { analytic }\end{array}$} & \multirow{3}{*}{6} & Synthetic & 68 & 81.9 & \multirow{3}{*}{0.685572} & \multirow{9}{*}{0.47654} \\
\hline & & Situational & 5 & 6.0 & & \\
\hline & & Analytic & 10 & 12.0 & & \\
\hline & \multirow{6}{*}{21} & Synthetic & 28 & 33.7 & \multirow{3}{*}{0.371143} & \\
\hline & & Situational & 15 & 18.0 & & \\
\hline & & Analytic & 40 & 48.1 & & \\
\hline & & Synthetic & 34 & 41.0 & \multirow{3}{*}{0.372906} & \\
\hline & & Situational & 13 & 15.7 & & \\
\hline & & Analytic & 36 & 43.4 & & \\
\hline \multirow{6}{*}{$\begin{array}{c}\text { Analogue-- } \\
\text { digital }\end{array}$} & \multirow{3}{*}{7} & Analogue & 40 & 48.2 & \multirow{3}{*}{0.459301} & \multirow{6}{*}{0.432266} \\
\hline & & Situational & 3 & 3.6 & & \\
\hline & & Digital & 40 & 48.2 & & \\
\hline & \multirow{3}{*}{15} & Analogue & 44 & 53.0 & \multirow{3}{*}{0.405231} & \\
\hline & & Situational & 11 & 13.3 & & \\
\hline & & Digital & 28 & 33.7 & & \\
\hline \multirow{9}{*}{$\begin{array}{l}\text { Concrete- } \\
\text { abstract }\end{array}$} & \multirow{3}{*}{8} & Concrete & 43 & 51.8 & \multirow{3}{*}{0.419336} & \multirow{9}{*}{0.527182} \\
\hline & & Situational & 8 & 9.6 & & \\
\hline & & Abstract & 32 & 38.6 & & \\
\hline & & Concrete & 25 & 30.1 & & \\
\hline & 16 & Situational & 13 & 15.7 & 0.401998 & \\
\hline & & Abstract & 45 & 54.2 & & \\
\hline & & Concrete & 12 & 14.5 & & \\
\hline & 24 & Situational & 6 & 7.2 & 0.635028 & \\
\hline & & Abstract & 65 & 78.3 & & \\
\hline
\end{tabular}




\begin{tabular}{|c|c|c|c|c|c|c|}
\hline Scale & Item & & Frequency & $\%$ & $\begin{array}{c}\text { Simpson } \\
\text { In. }\end{array}$ & Average \\
\hline \multirow{9}{*}{$\begin{array}{l}\text { Random- } \\
\text { sequential }\end{array}$} & \multirow{3}{*}{9} & Random & 24 & 28.9 & \multirow{3}{*}{0.476932} & \multirow{9}{*}{0.494858} \\
\hline & & Situational & 7 & 8.4 & & \\
\hline & & Sequential & 52 & 62.7 & & \\
\hline & \multirow{3}{*}{17} & Random & 50 & 60.2 & \multirow{3}{*}{0.481046} & \\
\hline & & Situational & 4 & 4.8 & & \\
\hline & & Sequential & 29 & 34.9 & & \\
\hline & \multirow{3}{*}{25} & Random & 55 & 66.3 & \multirow{3}{*}{0.508669} & \\
\hline & & Situational & 6 & 7.2 & & \\
\hline & & Sequential & 22 & 26.5 & & \\
\hline \multirow{9}{*}{$\begin{array}{l}\text { Inductive- } \\
\text { deductive }\end{array}$} & \multirow{3}{*}{10} & Inductive & 62 & 74.7 & \multirow{3}{*}{0.597414} & \multirow{9}{*}{0.451661} \\
\hline & & Situational & 4 & 4.8 & & \\
\hline & & Deductive & 17 & 20.5 & & \\
\hline & \multirow{3}{*}{18} & Inductive & 53 & 63.9 & \multirow{3}{*}{0.473994} & \\
\hline & & Situational & 10 & 12.0 & & \\
\hline & & Deductive & 20 & 24.1 & & \\
\hline & \multirow{3}{*}{26} & Inductive & 37 & 44.6 & \multirow{3}{*}{0.429327} & \\
\hline & & Situational & 6 & 7.2 & & \\
\hline & & Deductive & 40 & 48.2 & & \\
\hline
\end{tabular}

Generally speaking, the Simpson's Diversity indices for all questions suggest the presence of moderate to high levels of diversity among students; ranging from 0.3 to 0.5 . However, a closer examination of the frequencies and percentages adds more details on this diversity. As shown in Table 4, students' responses to some items reveal high levels of variation, while others do not. For example, when it comes to item 7 which assesses the Analogue-Digital tendency of students, the number of students who prefer to learn using a straightforward language (which constitutes $48.2 \%$ of the whole sample) is quite identical to the number of Analogue learners (the ones who prefer to learn using metaphors and contextual links). Another example is item 26 in the Inductive-Deductive domain: the number of students who prefer to learn inductively $(44.6 \%)$ is nearly close to the number of those who prefer to learn deductively (48\%). The fact that students from both poles in each domain are equal in number means that the diversity among learners is high. That is unlike when one category dominates the whole community as in items 21 and 6 , for example. In item 21 , the results reveal that the majority of students (83.1\%) are 
particular learners, whereas only $10 \%$ of them are global, and so is the case with item 6.

Based on these results, it can be concluded that in EFL classrooms, Synoptic learners as the ones who pay overt attention to grammatical rules and learn best through various means of Explicit Instruction equally co-exist with Ectenic learners who prefer to receive meaning-focused Implicit Instruction (Leaver et.al, 2005). This diversity among learners, according to the questionnaire results, calls for solutions and interventions. One solution is to evaluate the teaching methods used in class especially since education is now leaning towards learner-centered types of learning. This supports the argument made before that traditional methods of teaching such as the Grammar Translation Method with its emphasis on the direct teaching of grammar rules and the Communicative Language Teaching with its emphasis on inductive learning, are not enough to be used by their own. Consequently, this proves that students have preferred the diversity teaching in their EFL classrooms in order to meet their individual learning needs.

These results might as well be used as a possible justification for the inconsistency in the results of explicit and implicit instruction. As mentioned earlier, research under this domain has been classified into three types: 1) studies that support the explicit instruction (e.g., Ashman et al., 2020; Ellis, 2005; Hughes et al., 2017; Kim \& Lantolf, 2018; Robinson, 1996); 2) studies that favor implicit instruction (Chan, 2019; Godfroid, 2016; Hwu et al., 2013; Li et al., 2019; Shrum, 2015); 3) studies that view both approaches as equally effective (e.g., Doughty, 1991). If we were to reexamine this issue in the light of the current results, we could argue that the dynamic nature of language learners, which results from their individual differences, might be the reason why there is no clear-cut answer to which of the two either-or methods is better than the other. We could, hence, argue that explicit instruction might have proven its effectiveness due to the dominance of synoptic learners, and vice versa. Furthermore, the huge cognitive diversity among students might be the decisive factor as to why some studies found both approaches as equally effective. The latter supports Ellis' $(2006,2009)$ recommendation for future researchers to combine both approaches and getting the benefits of each.

In her book, The Differentiated Classroom, Tomlinson (2014) argues that there are three reasons behind using 'differentiated instruction' as a method of teaching; these include enhancing the efficiency of learning, increasing learners' motivation and allowing learners to have good access to the lesson. 
Surprisingly, two of the themes that emerged from learners' response are directly proving that application of differentiated instruction has successfully contributed to two of Tomlinson's reasons: learners' motivation and the way they access the lesson. The third theme, however, is believed to be partially related to the efficacy of learning.

On another level, the first theme, which is the increase of learners' motivation, as one benefit of differentiated instruction, supports other researchers' argument that if the teacher adapted his or her instruction to meet students' variation, students' self-image as learners improves (Corazza et al, 1995, cited in Salvisberg, 2005; Dörnyei, 2014). The increase of learners' motivation is an example of this improvement. Furthermore, the other themes, which are the appropriateness of access and learners' autonomy, confirm Baecher's et al. (2012) assertion that the purpose of differentiated instruction is neither to make heterogeneous groups homogeneous nor to transform the traditional learning environment completely. Instead, the core of differentiated instruction, as illustrated by Benjamin (2006), is the appreciation of rituals and varieties. Rituals refer to norms and expectations already existing, whereas varieties provide excitement and freedom of choice.

\section{Pedagogical Implications}

There are some considerable educational reasons to place matters of the $\mathrm{E}$ \& L construct high on the agenda for SLA research. First, this study is built on the premise that the cognitive diversity among language learners might and might not be considerable. If the diversity has been found to be huge, then it will contribute to one of the critical questions in SLA; the question of why L2 learners are not as successful as L1 acquirers. This correlation tightens up its theoretical underpinnings against the overwhelming criticism directed to the field of learning styles in general.

Based on the results of this study, there are some implications that must be highlighted in order to enhance the profession of language teaching in higher education. First, it is recommended that the academic staff at tertiary educational level consider using differentiated instruction when planning teachers' training programs and professional programs and courses, and when setting the criteria for evaluating teachers' performance in class. Second, the notion of individual differences is pivotal to be understood by both language teachers and students in EFL settings. Stakeholders should understand the 
cognitive diversity in various settings where learners may learn English for various goals and needs. Individual differences should be acknowledged in English language teaching classrooms. For example, factors including students' personality, learning needs and goals, willingness to communicate and motivation should be considered in students' language acquision process (Chamorro-Premuzic, 2016; Kidd et al., 2018; Suzuki \& DeKeyser, 2017). For example, we would advocate more communications between teachers and students. Students' prompt feedback will help teachers to revise and update their teaching and thus contributes to the whole program. Third, language teachers should be encouraged to participate in planning circles where they can collaborate and create differentiated learning resources, including contentbased materials, in and out of class activities and assignments (AlHashemi \& Elyas, 2018). The purpose of creating such circles is to tailor the base on which teachers can independently, yet gradually, use this method of teaching. Fourth, language teachers should understand that English should not be learned in a vacuum. Various activities should be incorporated into language classrooms to meet the various needs of learners. Learners should be provided with options to express themselves both during and after class, both in face-to-face and online communication modes. This also echoes English language teaching as collaboration will enable teachers to maximize teaching resources and materials during their teaching experience. A diversity of utilizing learning materials will make good use of resources application for curriculum development and maximizing learners' language learning capability.

\section{CONCLUSIONS}

This study started with a theory-driven interest in the factors that make some language learners more successful than others. Using the Ehrman and Leaver's (2003) model of cognitive profiles, it attempted to check whether or not EFL learners at a Saudi university differ in terms of their cognitive profiles. The results revealed that the cognitive diversity among students is considerable ranging between moderate and high. Based on the results, several implications were suggested to improve the quality of EFL teaching at the university level. Committees or units concerned with qualification assurance or professional development, for example, are highly recommended to take mixed-method languages teaching approaches, such as eclecticism and Differentiated Instruction, into consideration when planning teachers' training programs and 
when setting the criteria based on which teachers' performance will be later on assessed.

\section{REFERENCES}

AlHashemi, B., \& Elyas, T. (2018). Investigating the effect of differentiated instruction in light of the E \& L construct on grammar learning. Arab World English Journal, 9(3), 145-162.

Ashman, G., Kalyuga, S., \& Sweller, J. (2020). Problem-solving or explicit instruction: Which should go first when element interactivity is high? Educational Psychology Review, 32(1), 229-247.

Baecher, L., Artigliere, M., Patterson, D. K., \& Spatzer, A. (2012). Differentiated instruction for English language learners as "variations on a theme." Middle School Journal, 43(3), 14-21.

Benjamin, A. (2006). Valuing differentiated instruction. The Education Digest, 72(1), 57-59.

Bozhovich, E. D. (2009). Zone of proximal development: The diagnostic capabilities and limitations of indirect collaboration. Journal of Russian \& East European Psychology, 47(6), 48-69.

Brown, H. D. (2006). Principles of language learning and teaching (5th ed.). Longman.

Chamorro-Premuzic, T. (2016). Personality and individual differences (3rd edn.). Wiley.

Chan, M. (2019). The role of classroom input: Processing instruction, traditional instruction, and implicit instruction in the acquisition of the English simple past by Cantonese ESL learners in Hong Kong. System, 80, 246-256.

Cronbach, L. J. (1951).Coefficient alpha and the internal structure of tests. Psychometrika, 16, 297-334.

Dörnyei, Z. (2014). The psychology of the language learner: Individual differences in second language acquisition. Routledge.

Dörnyei, Z., \& Csizér, K. (2012). How to design and analyze surveys in SLA research? In A. Mackey \& S. Gass (Eds.), Research methods in second language acquisition: A practical guide (pp. 74-94). Wiley-Blackwell.

Doughty, C. (1991). Second language instruction does make a difference: Evidence from an empirical study of SL relativization. Studies in Second Language Acquisition, 13(4), 431-469. 
60 TEFLIN Journal, Volume 31, Number 1, January 2020

Ehrman, M. (1996). Understanding second language learning difficulties. Sage.

Ehrman, M., \& Leaver, B. L. (2003). Cognitive styles in the service of language learning. System, 31(3), 393-415.

Ellis, N. C. (2005). At the interface: Dynamic interactions of explicit and implicit language knowledge. Studies in Second Language Acquisition, $27(2), 305-352$.

Ellis, R. (2006). Current issues in the teaching of grammar: An SLA perspective. TESOL Quarterly, 40(1), 83-107.

Ellis, R. (2009). Implicit and explicit learning, knowledge and instruction. In R. Ellis, S. Loewen, C. Elder, R. Erlam, J. Philp, \& H. Reinders (Eds.), Implicit and explicit knowledge in second language learning, testing and teaching (pp. 3-25). Multilingual Matters.

Fang, F. (2017). English as a lingua franca: Implications for pedagogy and assessment. TEFLIN Journal, 28(1), 57-70.

Fang, F. (2018). Ideology and identity debate of English in China: Past, present and future. Asian Englishes, 20(1), 15-26.

Godfroid, A. (2016). The effects of implicit instruction on implicit and explicit knowledge development. Studies in Second Language Acquisition, 38(2), $177-215$

Hammer, Ø., Harper, D. A. T., \& Ryan, P.D. (2001). Past: Paleontological statistics software package for education and data analysis. Palaeontologia Electronica, 4(1), 1-9.

He, F., \& Hu, X.-S. (2005), Hubbell's fundamental biodiversity parameter and the Simpson diversity index. Ecology Letters, 8, 386-390.

Hughes, C. A., Morris, J. R., Therrien, W. J., \& Benson, S. K. (2017). Explicit instruction: historical and contemporary contexts. Learning Disabilities Research \& Practice, 32(3), 140-148.

Hwu, F., Pan, W., \& Sun, S. (2013). Aptitude-treatment interaction effects on explicit rule learning: A latent growth curve analysis. Language Teaching Research, 18(3), 294-319.

Jarvis, S. (2013), Capturing the diversity in lexical diversity. Language Learning, 63(S1), 87-106.

Jones, M. G., \& Brader-Araje, L. (2002). The impact of constructivism on education: Language, discourse, and meaning. American Communication Journal, 5(3),1-10. 
Elyas, Bayan \& Fang, Cognitive Diversity among EFL Learners 61

Kepple, G. (1991). Design and analysis: A researcher's handbook (3 ${ }^{\text {rd }}$ ed.). Prentice-Hall.

Kidd, E., Donnelly, S., \& Christiansen, M. H. (2018). Individual differences in language acquisition and processing. Trends in Cognitive Science, 22(2), 154-169.

Kim, J., \& Lantolf, J. P. (2018). Developing conceptual understanding of sarcasm in L2 English through explicit instruction. Language Teaching Research, 22(2), 208-229.

Kwak, T. J., \& Peterson, J. T. (2007). Community indices, parameters, and comparisons. In C. S. Guy, \& M. L. Brown, (Eds.), Analysis and interpretation of freshwater fisheries data (pp. 677-763). American Fisheries Society, Bethesda, Maryland.

Lantolf, J., Thorne, J. \& Poehner, M. (2015). Sociocultural theory and second language development. In B. VanPatten, \& J. Williams (Eds.), Theories in second language acquisition ( $2^{\text {nd }}$ ed.) (pp. 207-226). Routledge.

Larochelle, M., Bednarz, N. \& Garrison, J. (1998). Constructivism and education: Beyond epistemological correctness. Cambridge University Press.

Leaver, B. L., Ehrman, M., \& Shekhtman, B. (2005). Achieving success in second language acquisition. Cambridge University Press.

Li, S., Ellis, R., \& Zhu, Y. (2019). The associations between cognitive ability and L2 development under five different instructional conditions. Applied Psycholinguistics, 40(3), 693-722.

Lightbown, P. M., \& Spada, N. (2013). How languages are learned - Oxford handbooks for language teachers. Oxford University Press.

Mazloomi, S., \& Khabiri, M. (2018). The impact of self-assessment on language learners' writing skill. Innovations in Education and Teaching International, 55(1), 91-100.

McNamara, M. J., \& Deane, D. (2006). Self-assessment activities: Toward language autonomy in language learning. TESOL Journal, 5(1), 17-21.

Olusegun, S. (2015). Constructivism learning theory: A paradigm for teaching and learning. IOSR Journal of Research \& Method in Education Ver. I, 5(6), 2320-7388.

Ortega, L., \& Han, Z. (Eds.). (2017). Complexity theory and language development: In celebration of Diane Larsen-Freeman. John Benjamins. 
Robinson, P. (1996). Learning simple and complex second language rules under implicit, incidental, rule-search, and instructed conditions. Studies in Second Language Acquisition, 18(1), 27-67.

Roosevelt, F. D. (2008). Zone of proximal development. In N. J. Salkind (Ed.), Encyclopedia of educational psychology. Sage.

Salvisberg, J. (2005). Cognitive style and learning strategies. In IATEFL Issues. Retrieved March 6, 2020, from https://associates.iatefl.org/pages/ materials/voicespdf/ltskills8.pdf

Seidlhofer, B. (2011). Understanding English as a lingua franca. Oxford University Press.

Shrum, J. L. (2015). Teacher's handbook, contextualized language instruction. Cengage Learning.

Simpson, E. H. (1949). Measurement of diversity. Nature, 163(4148), 688-688.

Skehan, P. (1998). A cognitive approach to language learning. Oxford University Press.

Stephens, M. (2017). Applying the skill of inferring to learning vocabulary: A call to move from details to discourse. Critical Thinking and Language Learning, 4(1), 12-28.

Subban, P. (2006). Differentiated instruction: A research basis. International Education Journal, 7(7), 935-947.

Suzuki, Y., \& DeKeyser, R. (2017). The interface of explicit and implicit knowledge in a second language: Insights from individual differences in cognitive aptitudes. Language Learning, 67(4), 747-790.

Tomlinson, C. A. (2014). The differentiated classroom: Responding to the needs of all learners. Association for Supervision \& Curriculum Development.

Vakili, S., \& Ebadi, S. (2019). Exploring EFL learners developmental errors in academic writing through face-to-Face and Computer-Mediated dynamic assessment. Computer Assisted Language Learning. https://doi.org/10.1080/09588221.2019.1698616

Vygotsky, L. (1978/1995). Mind in society: The development of higher psychological processes. (M. Cole, V. John-Steiner, S. Scribner, \& E. Souberman, Eds., and Trans.). Harvard University Press. 
Elyas, Bayan \& Fang, Cognitive Diversity among EFL Learners 63

\section{Appendix 1. E \& L Learning Style Questionnaire v. 2.0 copyright Ehrman et al. (2003)}

\section{INSTRUCTIONS: Date:}

Mark in the space for each pair of items what you think you are like. For example, if you like bicycling much more than swimming, you might mark in space 2 (or even 1), like this:

I like riding a bicycle.

I like swimming.

0. $\quad$ Most like this

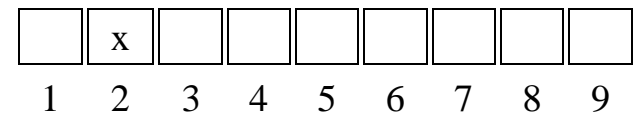

Most like this

If you sort of like swimming better, you might mark in space 6 .

I like riding a bicycle.

I like swimming.

0. Most like this

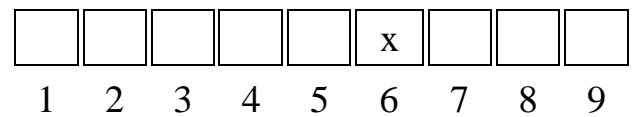

Most like this

If you think you are in the middle or really do both equally, use space 5. Try to avoid using space 5 if you can.

I like riding a bicycle.

I like swimming.

0. $\quad$ Most like this

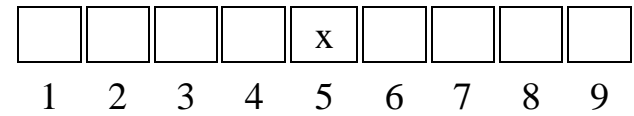

Most like this

There are no right or wrong answers on this questionnaire. 
Here are the questions:

1. When I work with new language I don't usually get much from in context, in stories or articles or at sentences; I often pick up new words, ideas, etc., that way, the context unless I pay close attention to what I'm doing. (1a) without planning in advance.

1. Most like this

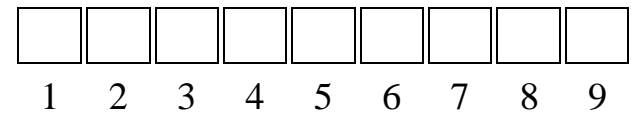

Most like this

2. When working with new material with additional subject matter around it, I comfortably find and use what is most important.

When there is a lot of information that comes with what I need to learn, it's hard to tell what's most important. It all seems to fall together sometimes, and it's hard work to sort things out. (2a)

2. Most like this

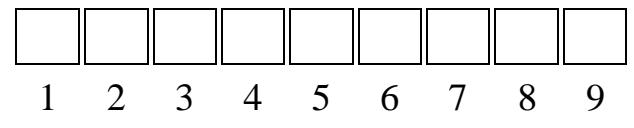

Most like this

I like to explore differences and disparities among things. (3a)

3. I like to reduce differences and look for similarities.

Most like this

3. Most like this

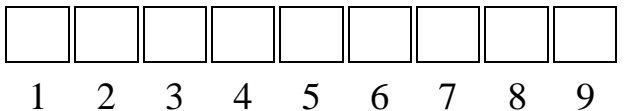

4. I tend to be most aware of the 'big picture.'

I notice specifics and details quickly. (4a)

4. Most like this

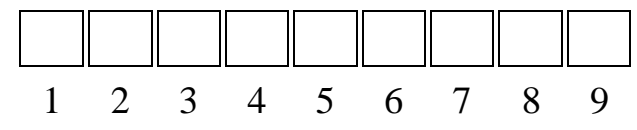

Most like this

5. I react quickly. I take my time to react. (5a)

5. Most like this

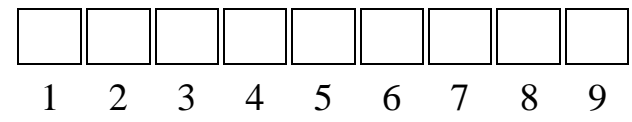

Most like this 
Elyas, Bayan \& Fang, Cognitive Diversity among EFL Learners 65

6. I understand best by assembling

I understand best by what I'm learning into a whole.

disassembly of what I'm learning into its component

parts. (6a)

6. Most like this

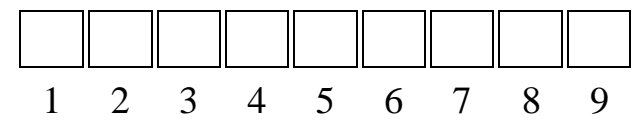

Most like this

7. I tend to learn things through metaphors.

I like it when people say what they mean directly. (7a)

7. Most like this

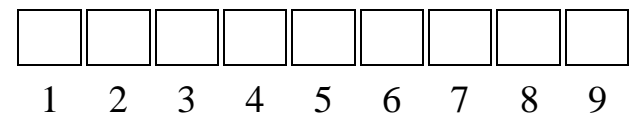

Most like this

$\begin{array}{lllllllll}1 & 2 & 3 & 4 & 5 & 6 & 7 & 8 & 9\end{array}$

8. To learn, I like to interact with the world.

I like to learn through concepts and ideas. (8a)

8. Most like this

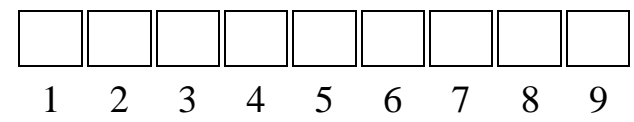

Most like this $\begin{array}{lllllllll}1 & 2 & 3 & 4 & 5 & 6 & 7 & 8 & 9\end{array}$

9. I learn best when I can work out for myself the best sequence to use, even if it's different from I learn best when there is a sequence of steps provided, so I the one in the book or lesson. can do things in order. (9a)

9. Most like this

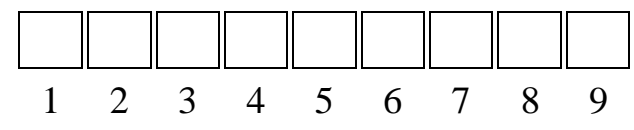

Most like this $\begin{array}{lllllllll}1 & 2 & 3 & 4 & 5 & 6 & 7 & 8 & 9\end{array}$

10. When I learn, I mostly start with examples or my experience and make generalizations or rules.

When I learn, I mostly start with rules and generalizations and apply them to my experience to learn. (10a)

10. Most like this

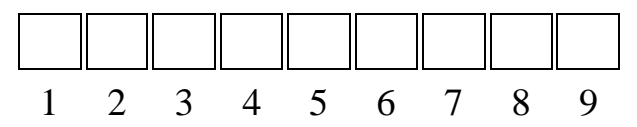

Most like this 
66 TEFLIN Journal, Volume 31, Number 1, January 2020

11. I often find that I have picked up new words, phrases, and so on without realizing it.
I usually have to undertake focused study before I learn new words or phrases. I wouldn't describe myself as someone who learns by 'osmosis.' (1b)

11. Most like this

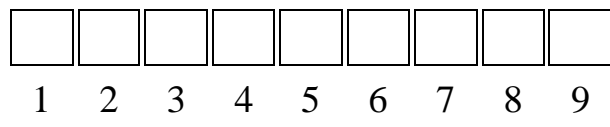

Most like this

12. I like out-of-context material like grammar rules.

Grammar rules and pieces of language that are out of context are hard for me to work with. (2b)

12. Most like this

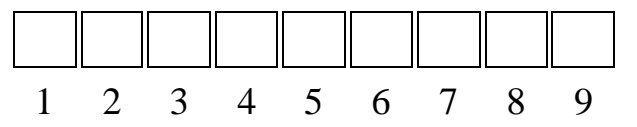
Most like this

13. I notice mostly how things are similar.

I quickly notice differences, even fairly fine distinctions. (3b)

13. Most like this

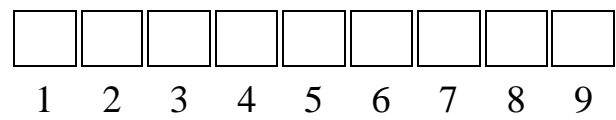

Most like this

14. I notice the 'forest' before the 'trees.'

I tend to be aware of the 'trees' before the 'forest.' (4b)

14. Most like this

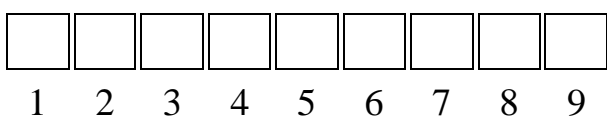

Most like this $\begin{array}{lllllllll}1 & 2 & 3 & 4 & 5 & 6 & 7 & 8 & 9\end{array}$

15. I don't have to spend much time preparing for something;

Before starting anything, I want instead, I start off working time to orient myself to it. (5b) immediately.

15. Most like this

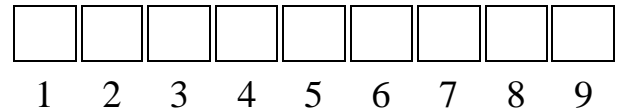

Most like this 
Elyas, Bayan \& Fang, Cognitive Diversity among EFL Learners 67

16. I often make up new words or sentences using language I already know.

I seek to understand the system that is behind words and sentences by pulling them apart in my mind. (6b)

16. Most like this

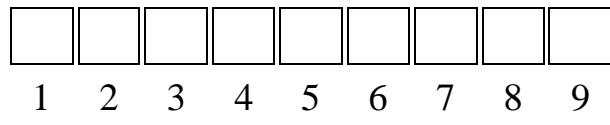

Most like this

17. I prefer to learn by using lots of associations.

I prefer to use rehearsal and repetition. (7b)

17. Most like this

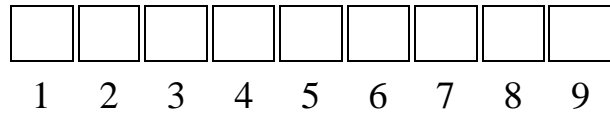

Most like this

$$
\begin{array}{lllllllll}
1 & 2 & 3 & 4 & 5 & 6 & 7 & 8 & 9
\end{array}
$$

18. I like to learn through applying knowledge and theory.

I like to learn through descriptions and grammars that formally represent knowledge. (8b)

18. Most like this

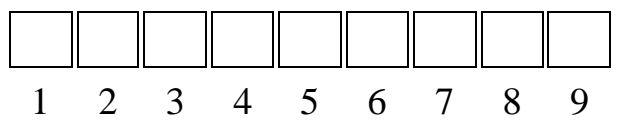

Most like this

19. Too much emphasis on a Organized textbooks and lesson curriculum or textbook can get in the way of my learning.

19. Most like this

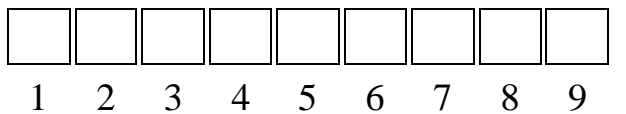

Most like this

$$
\begin{array}{lllllllll}
1 & 2 & 3 & 4 & 5 & 6 & 7 & 8 & 9
\end{array}
$$

20. I like to figure out grammar rules for myself.

I prefer to get the grammar rules from the teacher or a book. (10b)

20. Most like this

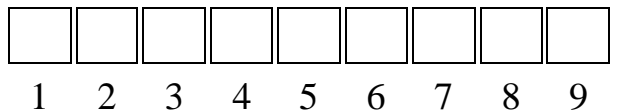

Most like this

21. I learn best from language that is in meaningful context like

I don't like to have to learn from just conversations, informal 
68 TEFLIN Journal, Volume 31, Number 1, January 2020

stories and conversations.

language use, or readings for native speakers that I haven't been prepared for. (1c)

21. Most like this

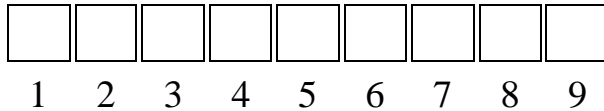

Most like this

22. When faced with new language, I re-conceptualize it so that it makes sense in my own terms.

I accept what is presented to me and take it pretty much as presented. (2c)

22. Most like this

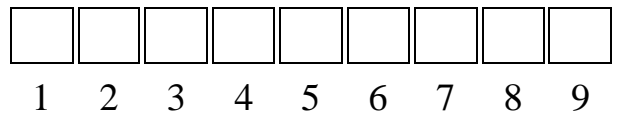

Most like this

$\begin{array}{lllllllll}1 & 2 & 3 & 4 & 5 & 6 & 7 & 8 & 9\end{array}$

23. I tend not to remember small distinctions, such as those

I have a good memory for fine between similar-seeming words or symbols. distinctions such as those between similar-seeming words or symbols. (3c)

23. Most like this

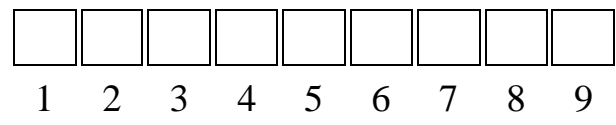

Most like this

I begin with the details to work up to the main points. (4c)

24. I start with the main points and work down to the details.

Most like this

24. Most like this

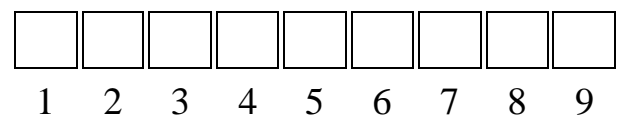

Most like this

25. I often act or speak without thinking about it.

I tend to think about things before I do or say them. (5c)

25. Most like this

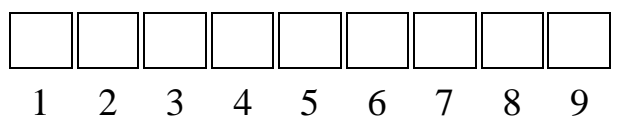

Most like this

26. I sometimes make up new ways to say things.

I prefer figuring out how words and sentences are put together. (6c) 
Elyas, Bayan \& Fang, Cognitive Diversity among EFL Learners 69

26. Most like this

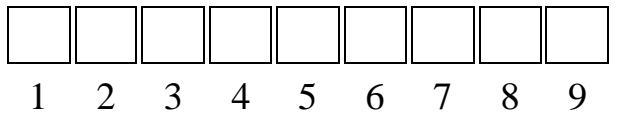

Most like this

It's usually okay to take what

I'm learning at face value. (7c)

27. It helps to understand the meanings behind the actual words.

27. Most like this

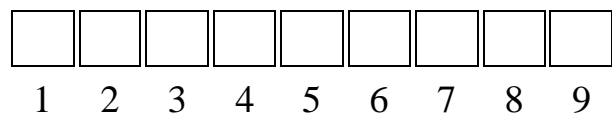

Most like this

I prefer to learn abstractly through theories. (8c)

28. I like learning when I can touch, see, or hear.

Most like this

28. Most like this

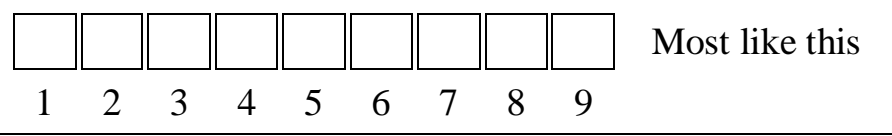

29. It doesn't matter if the material I'm learning isn't very

It's important to go step-by-step organized; I can find a way to as I learn. (9c) use it.

29. Most like this

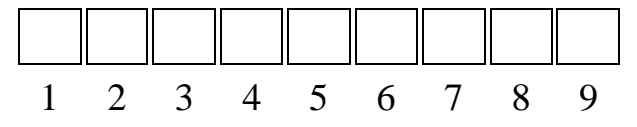
Most like this

30. When learning, I make guesses and then seek evidence to confirm or modify my ideas.

When learning, I would rather learn what I need to know directly, without fumbling around. (10c)

30. Most like this

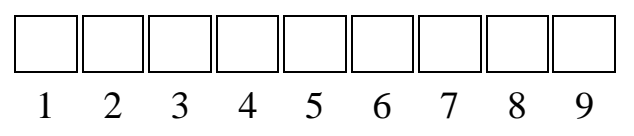

Most like this 